\title{
モルヒネ反復投与によるマウス自発運動促進効果に 対する逆而性の形成とその特徴
}

\author{
飯 塚 正 博, 平林 牧 三 \\ 群馬大学医学部行動医学研究施設行動分析学部門* \\ （昭和58年 7 月13日〔特〕）
}

\begin{abstract}
要約：dd 系成熟雄マウスに morphine (MOR) $5 ， 10$ および $20 \mathrm{mg} / \mathrm{kg}$ を1日，3〜4日あ るいは 7 日間隔で 10 回反復皮下投与し，そのつど 180 分間にわたり自発運動活性を測定し， 効果の変遷について検討した. MOR 初回投与時にはマウスの自発運動活性は用量依存的に促 進し，その効果は投与 $60 \sim 90$ 分後をピークとし，約 180 分間持続した. MOR の反復投与に よってての自発運動促進効果は, $5 \mathrm{mg} / \mathrm{kg}$ 投与群では明膫でなかったが, 10 および $20 \mathrm{mg} / \mathrm{kg}$ 投与群では投与回数に比例して増強され，いわゆる逆耐性か認められた．すなわち，いずれの 投与間隔であっても，3〜4回目までは進行性の効果増強がみられ，投与間隔が長い方が作用 持続時間の延長が著明な傾向が認められた。.また， $5 \sim 6$ 回目以降の投与時にみられる自発運 動促進効果の増強は頭打ちとなり，逆耐性が維持されるにとどまった１0 回に及ぶ MOR 反 復投与の後 2 汃月間休薬し，同量の MOR を投与した場合， 10 回目に比較すると明らかに自 発運動促進効果は減弱したが，なお初回時の効果に比し増強が認められた。 さらに，MOR 投 与後 180 分間移動空間の狭い広口ビンの中にマウスを閉じ込める操作を，1 日，3〜4日およ び 7 日それぞれの間隔で 5 回反復投与し， 6 回目に初めて測定容器に入れ自発運動活性を測定 すると, 運動促進効果は MOR 初回投与時あるいは生理的食塩水を反復投与し，そのつぞ同 様に運動阻害操作を施したマウスでみられた効果とほとんぞ同程度であり，逆耐性は全く観察 されなかった。
\end{abstract}

緒言

中枢作用楽にみられる多くの薬理作用は，反復投与した場合，耐性あるいは逆耐性が生ずることによって変 化する，中でも，逆耐性，つまり耐性とは逆に反復投与によって効果の増強が観察される現象については，最近， 薬物依存の形成過程などに関連して，各方面の研究者達の注目を集めるようになった．逆耐性という用語は，イ 又に cocaine を反復投与した際の行動変化が，遂次的に増強するという Tatum and Seevers ${ }^{1}$ の の報告に端を発 している. われわれも逆耐性現象に注目し，乙の10 年来いろいらの側面からの検討結果を報告してきた. すな わちラットやマウスに, d-amphetamine ${ }^{2)}$, cocaine ${ }^{3)}$ あるいは methamphetamine ${ }^{4)}$ の適当量を反復投与すると 条件によっては, それらの楽物が示す自発運動促進効果が投与回数に比例して, 進行的に増強し, さらにてのよ うな現象は，実験環境因子に関連した薬物效果の条件づけと深くかかわりあっているととを指摘してきた。

一方， morphine (MOR) は，上記薬物とは薬理作用を異にするが，マウスに投与した場合，特有な自発運 動活性の促進を示す. MOR をラットあるいはマウスに反復投与した場合の自発運動促進効果の変遷について は，逆耐性の形成をめぐって必ずしも意見が一定していない5,6)。その上それらの実験条件は整理されておらず， また MOR の逆耐性形成の特徴等についても明白にされているとはいえない. そてでわれわれは, MOR 反復投 与に伴なう自発運動活性促進効果に対する逆耐性の形成について, 系統的な実験条件を設定し検討を行なった。

実 験 方 法

\section{1. 実験動物}

本学医学部動物実験施設より供給された薬物体験の全くない dd 系雄性成熟マウスを用いた. すなわち生後

* E371 前橋市昭和町三丁目39-22 
21 日目に離乳し， 25 (繸) $\times 32$ (横) $\times 10$ (高) $\mathrm{cm}$ のアルミニウム製飼育箱中に $8 \sim 9$ 匹あて入れ, 固型飼料 $\mathrm{MF}$ （オリエンタル醉母社）と水道水を自由に与え，40日間飼育した。体重が $25 \sim 30 \mathrm{~g}$ に達したもの 447 匹を実験 に供した，全実験期間を通じ，マウスは自発運動測定時および薬物前処置実験以外は，同一飼育箱の中に置かれ た.

\section{2. 薬物}

morphine hydrochloride（武田薬品工業株式会社）を用い，投与量は $5 \mathrm{mg} / \mathrm{kg}, 10 \mathrm{mg} / \mathrm{kg}$ およぴ $20 \mathrm{mg} / \mathrm{kg}$ とした. また生理的食塩水投与の対照群をもうけた。. 薬物はすべて背部皮下に投与した. 薬物溶液は, 用量が、 ウス体重 $10 \mathrm{~g}$ 当り $0.05 \sim 0.1 \mathrm{ml}$ となるよう精製水で調製した.

\section{3. 自発運動測定方法}

マウスの自発運動活性 (SMA) については，田所と高野の創案つになる移所運動測定装置によって観測し た. この方法は振動カゴ法の一種で直径 $25 \mathrm{~cm}$ の底面積をもつ洗面器形円形容器の中に, 一匹あてのマウスを 入れ位置移動による容器の動きによって SMA を測定するてとを原理としている．マウスが $10 \mathrm{~cm}$ 内外の距離 を水平性に移動すると，カウンターが作動する．装置は簡便かつ安価なので同型の測定器多数を同時に使用でき る. しかし垂直性の運動については，測定の範团外にある．本測定方法の原理や特徴，測定例等の詳細について

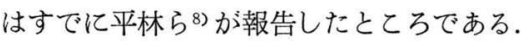

薬物投与前 30 分間，SMA を測定しマウスを測定環境に順応せしめた後，薬物投与を行ない， 10 分でとの 積算 SMA カウント数を 180 分間連続記録することを原則とした，反復投与間隔は，1 日ごと (daily)，3〜4 日 ごと (3 4 days) および 7 日ごと (weekly) とし, 測定ケージ内の投与では 10 回，広口ビン内投与では 5 回 MOR 投与を反復した. 同一マウスには，反復投与のたびに同一の測定ケージをあてがった．実験は午前 10 時 から午後 3 時までに終了するようにし，室温は $20^{\circ} \mathrm{C} \sim 25^{\circ} \mathrm{C}$ に維持した. 有意差検定は Student's- $t$ 検定によっ た．その他の実験方法の詳細については，実験結果の項で追加する。

\section{実 験 成 績}

\section{1. 反復投与に伴なうマウスの全身状態}

薬物投与操作を重礼るにしたがい，マウスは注射時のハンドリングに馿れ，薬物投与前の SMA は次第に低 值を示すようになった．MOR 投与によって約 10 分間，一過性の鎮静がみられ SMA も低值を示す傾向がみら れた，投与後 10 分を過ぎる頃より挙尾がみられ，同時に SMA 促進が出現し，挙尾反応の増強に比例して SMA 促進が高まり，一般に 50～90 分後に最高值になり，その後徐々に減衰するパターンを示した. SMA 促進効果 は, 用量が大きいほど強く，持続時間は延長した．SMA 観測は，180 分間行なったが，観察終了後にあっても 挙尾反応は，まだ残存していた．実験終了後飼育箱内では鎮静の傾向がみられた.

実験期間は，10７0 日以上に及んだが，MOR 反復投与によって，体重は減少せず，わずかではあるが増 加する傾向がみられ，その他特記すべき全身症状の変化は認められなかった．また肉眼的観察による運動促進の 特徴としてマウスは，等速性で曲線的に測定ケージ冈壁の周辺に沿って際限なく歩行するととが多かった.

\section{2. morphine 反復投与による自発運動活性促進効果の逆耐性について}

MOR $5 \mathrm{mg} / \mathrm{kg}$ を 1 日，3〜4 日および 7 日ごとに 10 回反復投与しても，SMA 促進効果には著明な変化 は検出されず，ピーク值で比較してもいずれの場合も，初回投与と 2 回目以上の反復投与時との間で有意差はな く，さらに投与を重ねてもほぼ同様の SMA 促進の増加を示すのみであったので，図は省略した．Fig. 1 は， MOR $10 \mathrm{mg} / \mathrm{kg}$ を 反復投与した場合の結果を示している. この図では，投与間隔でとに同一座標上に 10 回の 測定結果を重ねて示している. それぞれのカーブに近接して付した番号は投与回数を示しているが，カーブが複 蓶に重複している回については番号をつけなかった.

MOR による SMA 促進効果は，反復投与によっていずれの投与間隔にあっても，3〜4回目まで鮮明か つ進行的な増強を示している. しかし投与間隔の相違によって増強の程度には差が認められた. すなわちピーク 值の遂次的増大は，どの投与間隔でもほぼ同程度であったが，作用時間の持続は，投与間隔が長い方が，明らか 

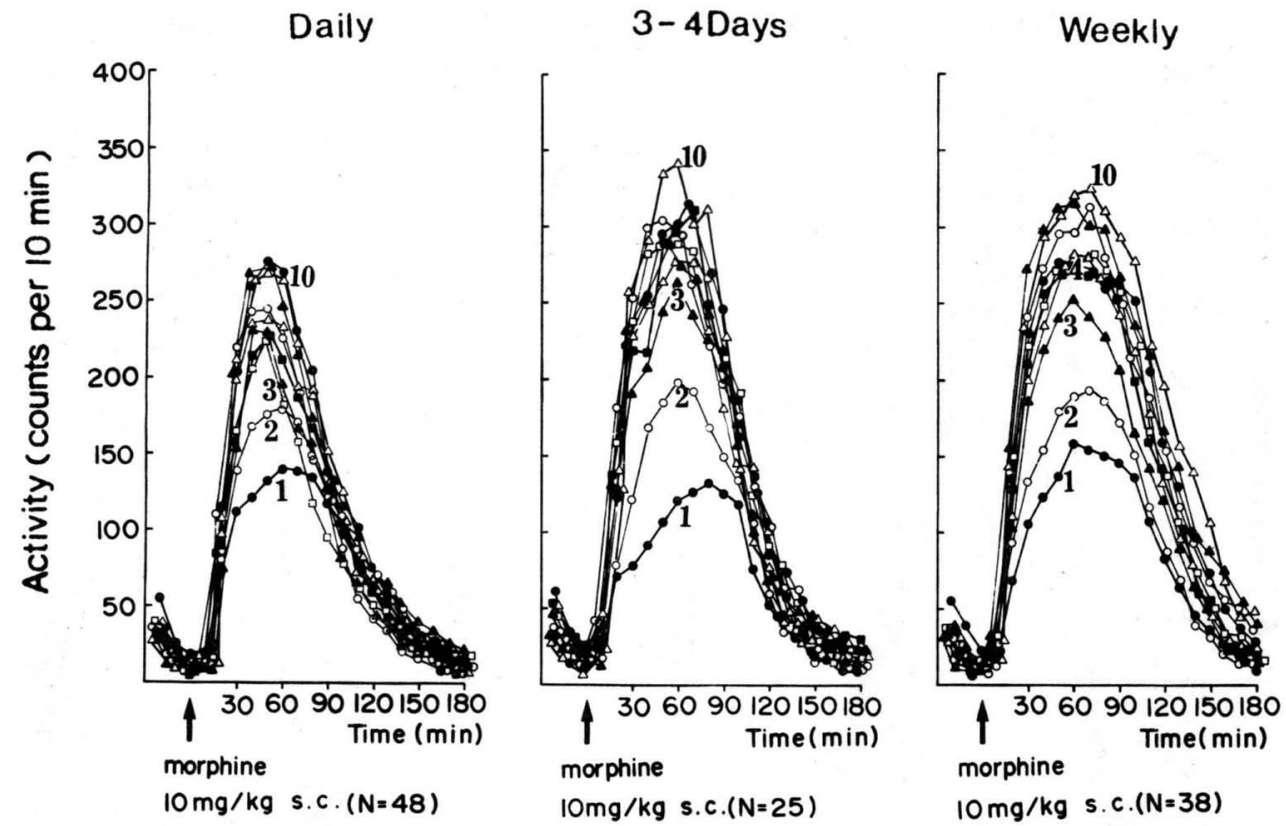

Fig. 1 Time course changes in mean ambulatory activity counts of mice after repeated administration of $10 \mathrm{mg} / \mathrm{kg}$ morphine s.c. at intervals of 1 day (daily), 3-4 days and 7 days (weekly). Morphine was administered after an adaptation period of $30 \mathrm{~min}$ for the activity cage, and the cumulative activity counts during $10 \mathrm{~min}$ segments were measured for $180 \mathrm{~min}$ thereafter. The figures near each curve denote ordinal numbers of administration.

に顕著であった. しかし $6 \sim 10$ 回目の投与時にはいずれの場合も効果増強の程度は小さくなり不明瞭になっ た.つまり SMA 促進効果に対する逆耐性は，約 5 回の反復投与で天井值に達し以後てれが維持される傾向が あったが，投与間隔が長い場合には作用持続時間の延長という形で逆耐性が進行すると考えられた．

Fig. 2 は MOR $20 \mathrm{mg} / \mathrm{kg}$ を反復投与した場合の SMA 促進パターンの変化を示している. $10 \mathrm{mg} / \mathrm{kg}$ 投 与の場合よりも鮮明で進行的な効果增強がみられた。 すなわち, MOR 反復投与でみられた逆耐性はいずれの投 与間隔でも $3 \sim 4$ 回目投与までは明らかに観察され, ピーク值の遂次的増大は 5 回目以降にほほ天井值に達し以 後これが維持された．作用時間の延長は投与間隔の長い方が顕著である特徴についても，10 $\mathrm{mg} / \mathrm{kg}$ 投与時とほ ぼ同様であった．挙尾反応についても反復投与によって発現時間の短縮が認められたが，挙尾の程度については 特別な定量的観察は行わなかった。

Fig. 3 は投与後 180 分間に及ぶ SMA 測定における総カウント数の変遷について，投与間隔別にわけて投 与回ごとに示し総括したものである. また，ての図には生理的食塩水の $3 \sim 4$ 日でとの反復投与の結果も示され ている. まず $5 \mathrm{mg} / \mathrm{kg}$ の連日反復投与条件下では，有意の変化はみられなかった．すなわち，比較的低用量の MOR 反復投与による効果の変化は極めて不明膫であったので省略した.

$10 \mathrm{mg} / \mathrm{kg}$ の反復投与では，連日投与条件下で SMA 促進パターンでみると効果増強がはっきりしない傾向 があったが, 総カウント数で比較すると 7 回目以降すべて初回投与時に比較し有意 $(\mathbf{P}<0.05)$ の増加が検出された. $3 \sim 4$ 日ごとおよび 7 日ごとの反復投与条件下では初回投与時の值に比較し， 3 回目以降すべて有意 $(\mathrm{P}<0.05)$ に高く明らかな増強がみられた。

$20 \mathrm{mg} / \mathrm{kg}$ 反復投与では，連日および $3 \sim 4$ 日ごとの投与条件下において 2 回目以降すべて有意 $(\mathbf{P}<0.05)$ に高く，また 7 日でとの投与条件下では，3 回目以降がすべて有意 $(\mathrm{P}<0.05)$ に高く，いずれの条件下におい ても明瞭な逆耐性が観察された。一方，生理的食塩水投与では全く変化が認められなかった。 

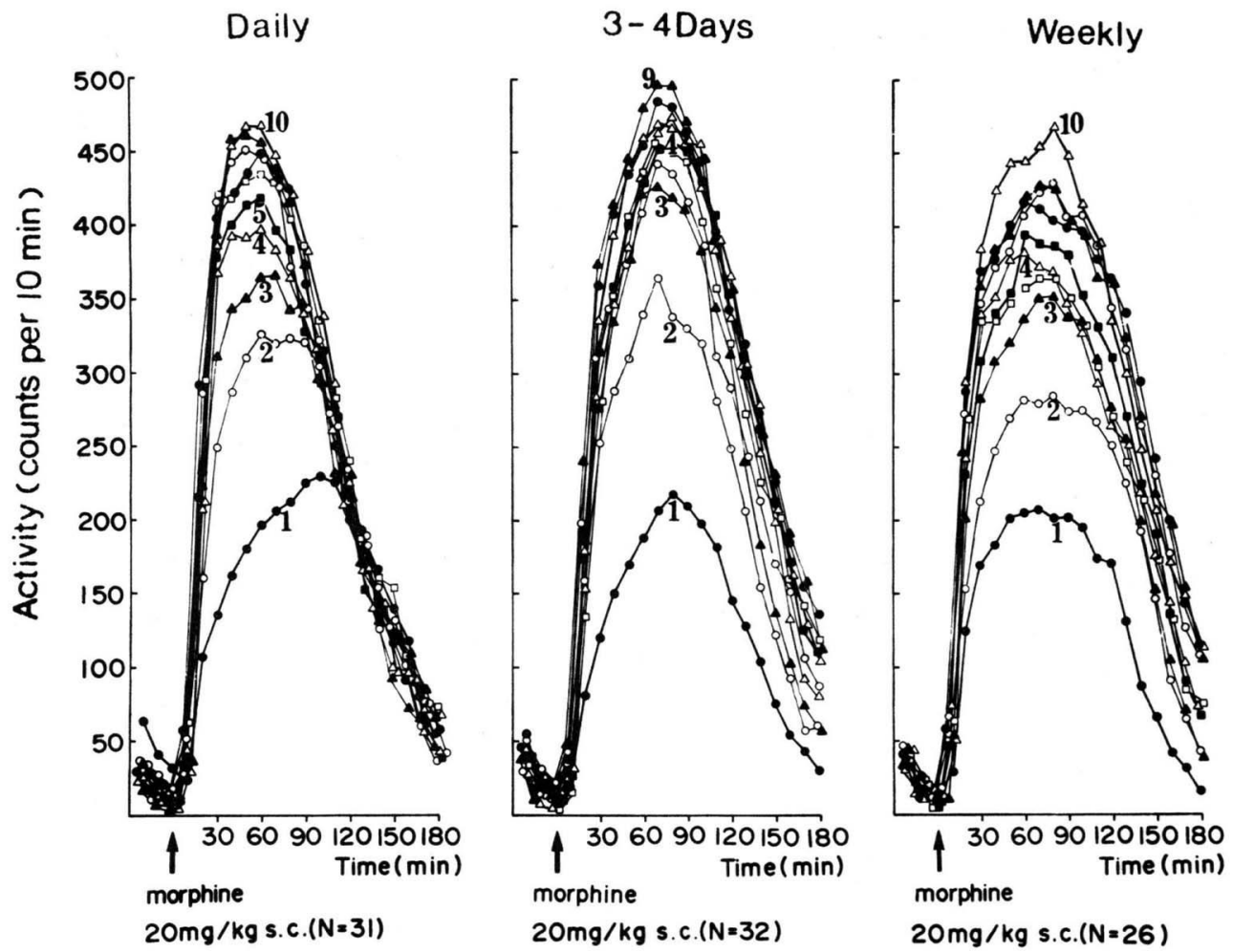

Fig. 2 Time course changes in mean ambulatory activity counts of mice after repeated administration of $20 \mathrm{mg} / \mathrm{kg}$ morphine s.c. at intervals of 1 day, 3-4 days and 7 days. The data are shown in the same way as in Fig. 1.

\section{Daily}

3-4Days

Weekly
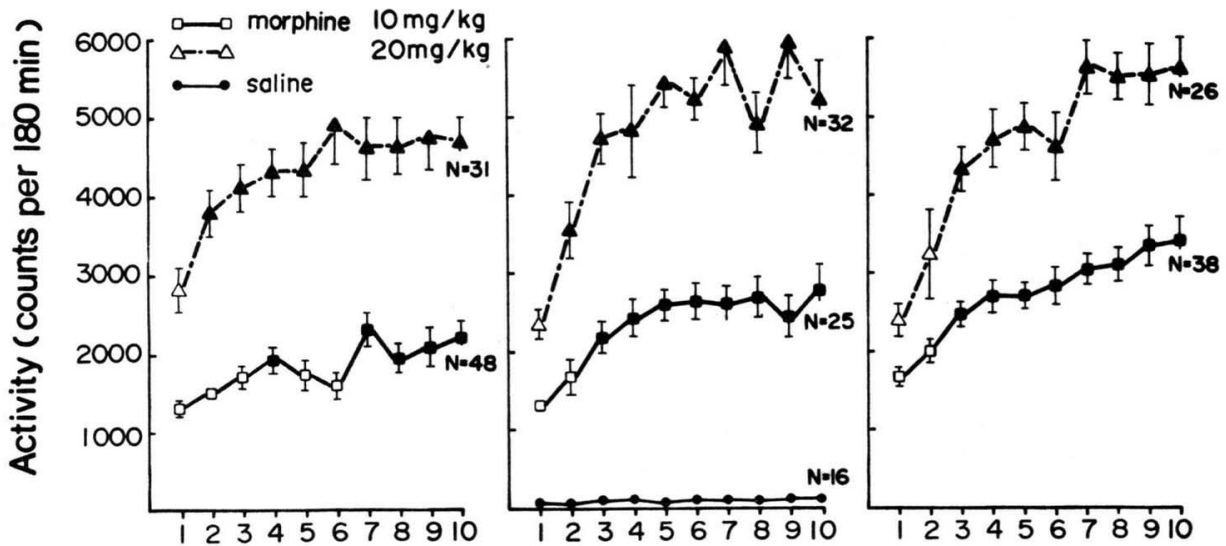

Ordinal No. of Administration

Fig. 3 Changes in mean overall ambulatory activity counts for $3 \mathrm{hr}$ after repeated administration of 10 and $20 \mathrm{mg} / \mathrm{kg}$ morphine s.c. at intervals of 1 day, 3-4 days and 7 days. The result after repeated administration of physiological saline at intervals of 3-4 days is also shown. The vertical line attached to each symbol indicates the standard error of the mean value. Filled symbols indicate statistically significant difference as compared with the value on the 1st administration within the group of mice. $(\mathrm{P}<0.05$, Student's $t$-test $)$. 


\section{3. 逆耐性の維持について}

MOR 10 回にわたって反復投与し，明らかに逆耐性が形成されたてとを確認したあと，2 か月間の休薬 期間を置き同量の MOR を再投与した場合の SMA 促進効果の変化について検討した.

Fig. 4 は, MOR $10 \mathrm{mg} / \mathrm{kg}$ を 3 4 日ごとに投与した場合の初回，10 回および 2 か月後に行った 11 回目 再投与時の SMA 促進パターンを示し，互いに比較したものである. なお生理的食塩水を 10 回にわたって反復 投与しても, 単に平坦なカーブを描くのみで変化が認められなかったので, 2 か月間休薬後の再投与実験は行わ なかった. 11 回目における MOR の SMA 促進効果は, 初回投与時のそれに比較して, 投与後 110 分から 160 分にわたって有意 $(\mathbf{P}<0.05)$ に高かったが他の時間帯では有意差がなかった. すなわち効果持続時間の延長の みが著明であった. 一方, 10 回目投与時の効果と比較すると, 11 回目では投与 30 分後から 80 分後の 60 分間に わたって SMA カウント数は有意 $(\mathrm{P}<0.05)$ 亿低かったが，他の時間帯では差がなかった．すなわち，ての時 間帯でみる限り逆耐性の明らかな減弱が認められたのである.しかし, 11 回目の SMA 促進パターンは初回投 与のそれとは明らかに異なり，逆耐性が消失しているとは考学られなかった。

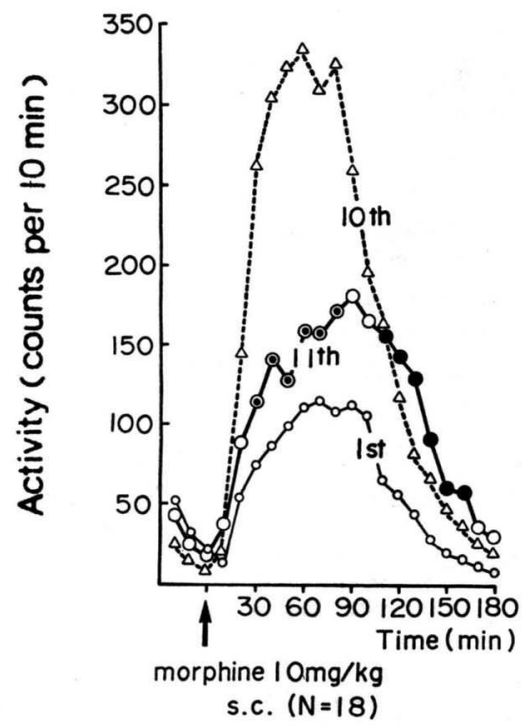

Fig. 4 Time course changes in mean ambulatory activity counts of mice after repeated administration of $10 \mathrm{mg} / \mathrm{kg}$ morphine s.c. The 1st-10th administrations were carried out at intervals of 3-4 days, and the 11th administration was held at 2 months after the 10th. indicates statistically significant difference as compared with the value on the lst administration $(P<0.05)$. ( ) indicates statistically sigificant difference as compared with the value on the 10th administration $(\mathrm{P}<0.05)$.

\section{MOR 投与後, 運動を阻害する処置を反復した後の SMA 促進効果について}

amphetamine 類の反復投与による SMA 促進効果の増強は, われわれの経験4,9〕にると, 比較的広い測定 ケージ内でマウスが自由に運動することに明らかに関連があるので, 本実験においても薬物投与でとに 180 分間 マウスを狭い空間に入れ，自由な運動を拘束する操作を 5 回反復した後に，6回目にはじめて測定ケーシシ内にお いた場合の SMA 促進効果について検討した. すなわち, 1 群を 32 匹とした 6 群のマウスをさらにそれぞれ 16 匹あてのサブグループに 2 分し, 一方には MOR の $10 \mathrm{mg} / \mathrm{kg}$ または $20 \mathrm{mg} / \mathrm{kg}$ を, 他方には生理的食塩水を 1，3〜 4 および 7 日でとの間隔で 5 回反復投与した. 投与直後から 180 分間にわたって 1 匹あてのマウスを広 ロビン（底面積直径 $6 \mathrm{~cm}$, 高さ $15 \mathrm{~cm}$ ) に閉じ込め, 物理的に運動を阻害した. 6 回目には生理的食塩水投与 群を含めすべてのマウスに同量の MOR を投与し, 初めて測定ヶージに移し SMA 促進効果を観察した. 


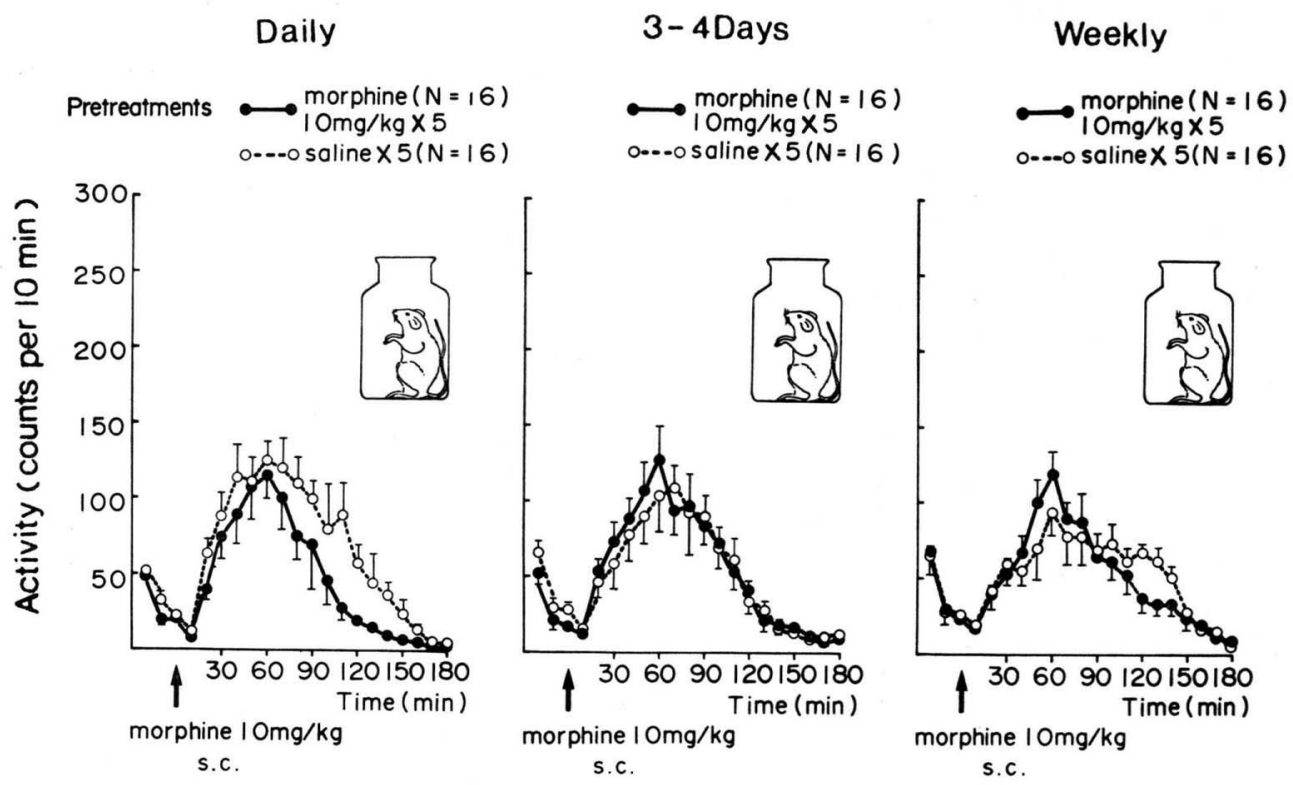

Fig. 5 Time course changes in mean ambulatory activity counts of mice after administration of $10 \mathrm{mg} / \mathrm{kg}$ morphine s.c. The mice had experienced the administration of $10 \mathrm{mg} / \mathrm{kg}$ morphine s.c. or physiological saline s.c. for 5 times at intervals of 1 day, 3-4 days and 7 days; and they had been confined in a glass jar of $6 \mathrm{~cm}$ in diameter and $15 \mathrm{~cm}$ height for $3 \mathrm{hr}$ after each administration. The vertical line attached to each symbol indicates the standard error of the mean value.
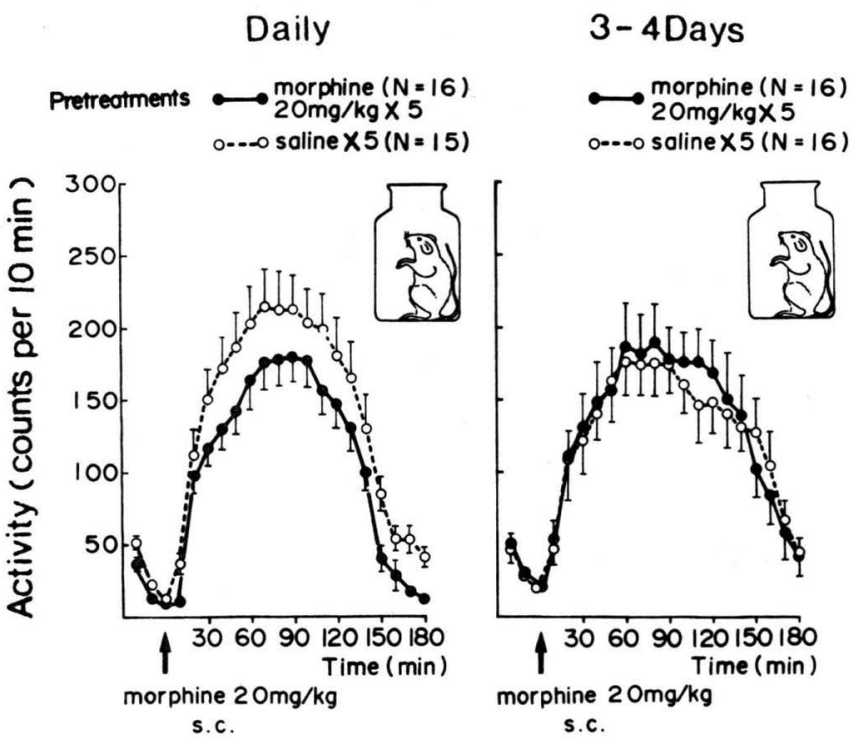

Fig. 6 Time course changes in mean ambulatory activity counts of mice after administration of $20 \mathrm{mg} / \mathrm{kg}$ morphine s.c. The mice had experienced the administration of $20 \mathrm{mg} / \mathrm{kg}$ morphine s.c. or physiological saline s.c. for 5 times at intervals of 1 day, and 3-4 days; and they had been confined in a glass jar of $6 \mathrm{~cm}$ in diameter and $15 \mathrm{~cm}$ height for $3 \mathrm{hr}$ after each administration. The data are expressed in the same way as in Fig. 5. 
Figs. 5 および 6 は，それぞれ MOR 10 および $20 \mathrm{mg} / \mathrm{kg}$ 投与時の SMA 測定結果を示している. この 図でみられるように，生理的食塩水前処置群における MOR 投与は，わずか 1 回のみであるが MOR 6 回反 復された SMA 前処置群と比較して MOR 促進効果の程度には大差なく, 両群間には有意差が認められず，か えって, MOR 前処置群の方が低值を示す傾向さ光認められた。 また，すべての条件下における SMA 促進パ ターンは，MOR を初回投与した場合に類似しており，Figs. 1 および 2 亿示された 6 回目の MOR 投与群の パターンとは明らが相違していた．肉眼的観察によるとビン詰め状態におけるマウスは，立ち上りや反転のみ が辛うじて可能なだけであったが，生理的食塩水投与群に比べ，MOR 投与群では動きが緩徐な傾向がみられ ビンの底で目を閉じ，うずくまるマウスが見られた。

\section{考 察}

ヒトあるいは実験動物に MOR の反復投与を行なった場合，鎮痛効果や缸醉感発現効果には耐性が生じや すいととが知られている ${ }^{10 \sim 12)}$. Seevers and Deneau ${ }^{13)}$ は，MOR には中枢神経系に対し抑制と興奪の両作用が あわせ存在するととを指摘している．MOR が示す幾多の薬理作用は反復投与によってダイナミックに変化する が，中枢に対する抑制性効果には耐性が，逆に興奮性効果には，逆耐性が差別的に生じ，各薬理作用ごとにレセ プターが相違するようにもみえる，マウスでみられる SMA 促進や挙尾反応は，興奮性効果を代表し14)，反復投 与によって増強されるのではないだろうか。

本実験結果によると，MOR 10 20 mg/kg の範囲内で，SMA 促進効果には反復投与によって明らかな逆 耐性が観察された. しかし， $5 \mathrm{mg} / \mathrm{kg}$ 反復投与時には逆耐性は不明瞭であった. また 10 および $20 \mathrm{mg} / \mathrm{kg}$ 投与 の場合，投与間隔が長い方が効果増強が明瞭の傾向があった。つまり，MOR 反復投与でみられる逆耐性は，用 量や投与間隔によって異なって発現すると考えられる.

逆耐性現象は, MOR の蓄積効果によるのではないかという疑いもあろう. しかし，MOR は投与 24 時間 後には，90\% 以上排泄されてしまうといわれている15)。 また，投与間隔が 3 時間のように極めて短かい場合に は, SMA 促進効果は反復投与によって, 逆に抑制され耐性様現象がみられるという16). いずれにせよ逆耐性現 象は投与間隔が長い方が明瞭であるととは蓄積効果とは矛盾している。しかし，SMA 促進効果をひきおてすた めには，鎮痛量よりはるかに大量を用いなくてはならない点には問題がないとはい光ない.

さて教室の Hirabayashi and $\mathrm{Alam}^{4)}$ によって報告された methamphetamine 反復投与時にみられる SMA 促進効果伩対する逆耐性と比較してみると，MOR でみられる逆耐性には次のような特性がある．つまり， MOR による逆耐性は比較的早い反復回数によって天井に達してしまうこと，休薬によって減弱しやすいてと， 逆耐性は投与60 70分後にみられるピーク時の值が上昇するととよりも効果の持続時間が延長する傾向があるこ と, さらに methamphetamine の逆耐性は SMA 促進効果だけではなく常同行動にもみられるが，MOR の逆 耐性は挙尾反応と同調するととなどがあげられる，さらにての時のマウスの運動状態を観察した場合，MORに よる SMA 促進は曲線的, 等速性で周辺指向性の傾向が強く際限なく歩き回るととが特徵であった. methamphetamine, d-amphetamine あるいは cocaine による SMA 促進は，直線的でジグザグに緩急入り混り，と くに迅速な動きが目立つようである.

これらの相違点は, MOR と覚醒剤の反復投与でみられる SMA 促進効果やその逆耐性には，それぞれ発 現機序に相違があることを想起せしめる.

すでに述べたように MOR には, 中枢に対し抑制と興奮の 2 つの相反する作用が存在すると考えると，抑

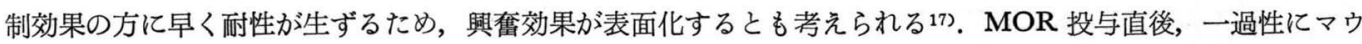
スが鎮静を示し，SMA が低值を示すととがしばしば観察されるととがあるが，ての持続時間が反復投与によっ て短縮される傾向もこのととをあらわしているのかもしれない.

本実験におけるビン詰め実験の結果は示唆に富んでいると思う.つまり, 生理的食塩水前処置群と MOR 前処置群の間には, SMA 増強効果に全く差が認められず, 狭い実験環境に MOR 投与後マウスを閉じ込めた 場合には，たとえ MOR を反復投与しても SMA 促進効果に対する逆耐性は発現しないのである.つまり逆耐 性発現の条件は，単に薬物を反復投与するだけでは不十分なととを意味している．とのととは本実験の結果のう 
ち重要な点の 1 つといえる. 実験環境と結びついた薬物効果の反復体験が逆耐性形成に密接に関係していると とを意味しているからである.つまり逆耐性形成の必要条件としてマウスが自由に移動可能な空間におかれてい るときに薬物を体験することが強調されるのである.

Rushton ら ${ }^{18)}$ は，中枢作用性の薬物効果は個体の薬物体験と現在の環境によって支配されると述べてお り, Schreiber ら 19) も, 個体の示す薬理作用の結果と実験環境との関連性を指摘している. われわれの経験によ ると同様の現象は, d-amphetamine ${ }^{2)}$, methamphetamine ${ }^{4)}$ あるいは cocaine ${ }^{32}$ でもみられ決して MOR 特有 なものではなく，また条件や観察指標によっては haloperidol ${ }^{20)}$ や diazepam ${ }^{21}$ 等の中枢抑制薬でも確認でき る. しかもとの変化が一旦形成されると容易に初回投与時のレベルに復帰しないてとは, 逆耐性の形成機序に半 永久的な脳内生化学的変化や実験操作と環境因子を条件刺激とする薬物効果の条件づけを想起せしめる. 最近, 鈴木ら 222は MOR によるマウスの SMA 促進効果の逆耐性が MOR 混入飼料を自由にいつでも摂取できる状 態で飼育した場合には出現せず，条件によっては耐性がみられることを報告している．条件づけの想定は，ヒト でみられる placebo 効果や薬物依存形成過程, その易再発性等の説明に関連してくるので注目に值する.

MOR の SMA 促進効果と脳内ァミンの消長とは関係があるといわれている。しかし, SMA と脳内ァ ンの変動に関する数々の報告は一定の方向を示していず, とくに種々の用量の MOR 投与による脳内カテコー ルアミンレベルの増減については意見が一致していない23-25). しかも逆而性との関連については全く観察され ていない.

われわれの経験によると ${ }^{2,16)} \mathrm{MOR}$ を反復投与していた動物に d-amphetamine, cocaine を投与すると SMA 促進効果の増大がみられ，交差逆耐性が考えられたが，逆に d-amphetamine， cocaine を反復投与し逆耐 性がみられたマウスに MOR を投与しても SMA 促進効果は著明に増強しないてとがあり，ての点の確認には 微妙なところがあった. MOR と d-amphetamine, cocaine との SMA 促進効果に対する作用機序が異なるの みではないかと考えている. Villareal ら 26 も, MOR と d-amphetamine とでは SMA 促進効果の作用機序は 異なっていると結論している.

MOR の SMA 促進効果はカテコールアミン性神経終末における noradrenaline 合成および放出の増加が 原因であるという考えもある27. また，MOR 投与時には脳内 ${ }^{14} \mathrm{C}$-tyrosine から ${ }^{14} \mathrm{C}$-noradrenaline への合成 促進が認められるといわれている28)。一方， reserpine を投与してカテコールアミンを枯渴せしめたり，あるい は $\alpha$-methyl-p-tyrosine によって tyrosine 水酸化醳素を抑えると MOR による SMA 促進効果が減弱すると いう報告もみられる26). しかし，逆耐性はあくまでもSMA の促進が原因となって形成されるものでカテコール アミン系の変動は単なる結果であるという考学も否定できない. Gunne ${ }^{29)}$ は MOR の投与量を増量してゆくと とによって逆耐性を確認している. Babbini ら ${ }^{300}$ は 30 日間 MOR をラットに連続投与して， $5 \mathrm{mg} / \mathrm{kg}$ 以下で わずかな興奮はみられたが， $10 \mathrm{mg} / \mathrm{kg}$ 以上で抑制と興奮の 2 つの相を見い出し中枢における 2 つの薬物受容体 を想定して SMA 増強作用を説明している. Vasco ら ${ }^{311}$ は, MOR の抑制および興奮効果に対する耐性々脳内 アセチールコリンの利用を関連づけて考察しているが，いずれも実験環境との関係を重視していない.

以上のようにシナプスレベルの神経伝達物質の変化あるいはレセプターレベルの問題だけで本実験結果をす べて説明するには残念ながら無理のような気がする. 今後は薬物投与と環境との関連をも含め, 広範な観点から 逆耐性問題の解明を進めてゆく必要が痛感されるのである.

謝辞 : 本研究をまとめるにあたり，たえず御懇切なる御指導をくださった田所作太郎教授なら びに御助言をいただいた栗原 久博士および御支援いただいた林 哲博士，藤本憲二氏および M.R. Alam 博士の諸氏に深く感謝申し上け゚ます.

\section{文献}

1) Tatum, A.L. And Seevers, M.H.: J. Pharmacol. Exp. Ther. 36, 401 (1929)

2) 田所作太郎：薬物と行動, p. 115, ソフトサイエンス社, 東京 (1980)

3) 平林 牧三, 柴崎 道子, 飯塚 正博, 田所作太郎：日薬理誌 71, 126P (1975) 
4) Hirabayashi, M. And Alam, M.R.: Pharmacol. Biochem. Behav. 15, 925 (1981)

5) Shuster, L., Webster, G.W. ANd Yu, G.: J. Pharmacol. Exp. Ther. 192, 64 (1975)

6) Shuster, L., Hannam, R.V. and Boyle, W.E., Jr.: J. Pharmacol. Exp. Ther. 140, 149 (1963)

7) 田所作太郎, 高野 介佐：日薬理誌 65, 229P (1969)

8) 平林 牧三, 飯塚 正博, 田所作太郎：日薬理誌 74, 629 (1978)

9) Alam, M.R.: Japan. J. Pharmacol. 31, 897 (1981)

10) Fernandes, M., Kluwe, S. And Coper, H.: Psychopharmacology (Berlin) 54, 197 (1977)

11) Goldstein, A. And Sheehan, P.: J. Pharmacol. Exp. Ther. 169, 175 (1969)

12) Kayan, S., Ferguson, R.K. and Mrtahell, G.L.: J. Pharmacol. Exp. Ther. 185, 300 (1973)

13) Seevers, M.H. and Deneau, G.A.: Arch. Int. Pharmacodyn. Ther. 140, 514 (1962)

14) Bilbey, D.L.J., Salem, H. and Grossman, M.H.: Br. J. Pharmacol. 15, 540 (1960)

15) Jaffe, J.H. and Martin, W.R.: The Pharmacological Basis of Therapeutics, Edited by Goodman, L.S. AND Gilman, A.: Fifth edition, p.245, Macmillan Publishing, New York (1975)

16) 田所作太郎：環境と順応，下田新一編，p. 19，広川書店，東京 (1978)

17) Seevers, M.H. and Deneau, G.A.: Physiological Pharmacology, Edited by Root, W.S. And Hoffman, E.G., Vol. 1, p.565, Academic Press, New York (1963)

18) Rushton, H., Steinberg, H. And Tomokiewicz, M.: Nature 220, 885 (1968)

19) Schreiber, H.L., Wood, W.G. And Garlson, R.H.: Pharmacol. Biochem. Behav. 4, 393 (1976)

20) 林哲, 田所作太郎：生物科学 32, 75 (1980)

21) Kuribara, H. and Tadokoro, S.: Japan. J. Pharmacol. 30, 264 (1980)

22) 鈴木 勉, 吉井 利郎, 柳浦 才三 : 日薬理誌 81, 227 (1983)

23) Gunne, L.M.: Nature 184, 1950 (1959)

24) Maynert, E.W. and Klingham, G.I.: J. Pharmacol. Exp. Ther. 135, 285 (1962)

25) Freedman, D.X., Fram, D.H. and Giarman, N.J.: Fed. Proc. 20, 321 (1961)

26) Villareal, J.E., Guzmann, M. and Smith, C.B.: J. Pharmacol. Exp. Ther. 187, 1 (1973)

27) Seiden, L.S. And Dykstra, L.A.: Psychopharmacology, a Biochemical and Behavioral Approach, p. 205, Van Nostrand Reinhold Company, New York (1977)

28) Smith, G.B., Villaleal, J.E., Bednarczyk, J.H. And Sheldon, M.I.: Science (Washington) 170, 1106 (1970)

29) Gunne, L.M.: Acta Physiol. Scand. 58, Supp. 204, 1 (1963)

30) Babbini, M. and Davis, W.M.: Br. J. Pharmacol. 46, 213 (1972)

31) Vasco, M.R. and Domino, E.F.: J. Pharmacol. Exp. Ther. 207, 848 (1978)

\begin{abstract}
Masahiro IIZUKA and Makizo HIRABAYASHI (Division for Behavior Analysis, Behavior Research Institute, Gunma University School of Medicine, Maebashi 371, Japan). Enhancing effect of morphine on ambulatory activity produced by repeated administration in mice. Folia pharmacol. japon. 82, $293 \sim 301$ (1983)

Characteristics of changes in ambulatory activity after repeated administration of morphine, $5,10 \mathrm{or} 20 \mathrm{mg} / \mathrm{kg}$ s.c., were investigated in male mice of dd strain. The drug was administered 10 times at intervals of 1 , 3-4 or 7 days, and the ambulatory activity of each mouse was measured by a tilting-type round activity cage with a $25 \mathrm{~cm}$ diameter for $180 \mathrm{~min}$ after each administration. Morphine, $5-20 \mathrm{mg} / \mathrm{kg}$ induced a dose-dependent increase in the ambulatory activity, and this effect attained to a peak at 60-90 min and persisted for 120-180 min after the administration. An augmentation of sensitivity (a reverse tolerance) to the ambulation-increasing effect of morphine was induced by the repeated administration of 10 and $20 \mathrm{mg} / \mathrm{kg}$ morphine, regardless of the intervals. The reverse tolerance achieved the maximum on the 5-6th administration day, and almost the same level of sensitivity was maintained until the 10th administration day. There was no significant difference in the activity counts at the peak time among the groups of mice varing the administration intervals. However, the persistence of increased ambulatory activity tended to be longer in the group of mice given morphine at intervals of 7 days than in the group given it at intervals of 1 day. The reverse tolerance, once produced, attenuated 2 months after the cessation of the repeated administration. However, the ambulatory activity counts did not return to those on the 1 st administration day. In contrast, development of reverse tolerance to the ambulation-increasing effect of morphine could not be observed when mice were put into a glass jar, in which the ambulation was completely restricted, for $180 \mathrm{~min}$ after each administration. The factors involved in the production of reverse tolerance to morphine are discussed.
\end{abstract}

